\title{
European INTEgration AND CZECH SOVEREIGNTY 'SYNCHRONIZED'
}

\author{
Four Basic Arguments in Defence of Preservation of Sovereign Statehood
}

\section{Ondrej Hamulák ${ }^{1}$}

\section{Faculty of Law, Palacký University Olomouc, Czech Republic email: ondrej.hamulak@upol.cz}

HAMULÁK, Ondrej. European Integration and Czech Sovereignty 'Synchronized'. Four Basic Arguments in Defence of Preservation of Sovereign Statehood. International and Comparative Law Review, 2014, Vol. 14., No. 2, pp. 41-58. DOI: $10.1515 /$ iclr-2016-0050.

\begin{abstract}
European integration entity ceased to be just a forum for negotiations between independent and sovereign nation states. To some extent it overlaps with the states and becomes their competitor. In this context, the classical concept of state sovereignty loses its original content and meaning. The participation in the integration project opens the question whether it takes away or weakens sovereignty of Member States? This paper puts on four arguments to proof the hypothesis that Czech Republic continues to be a sovereign country even after accession to the European Union.
\end{abstract}

Keywords: EU, Sovereignty, Czech Republic, Constitutional and Supranational Safeguards

\section{Introduction}

The process of European integration leads to a competition of power centres ${ }^{2}$ and to a certain degree of multi-level governance. The European Union has (to some extent) become a rival to nation states. At the same time, the European Union is a normative centre. It has its own independent legal system, which produces the internal effects in the Member State's practice and concurs the national law. EU undoubtedly profiles itself as an independent entity, as some kind of a sovereign power which independently and individually manages the agenda entrusted to it by a transfer of competences from Member States. The EU is a specific complex organism, which disposes of independent decision-making tools and own power mechanisms. It can autonomously and directly affect the legal status of legal subjects, and that makes it a form of public power, a self-governing subject, and a sovereign of its kind, which co-exists with its basic units.

Yet, despite the development and pressure of integration, the EU does not replace or absorb the nation states. There has not been any present constitutional

1 Lecturer in EU law, Faculty of Law, Palacký University in Olomouc, Czech Republic. E-mail: ondrej.hamulak@upol.cz.

2 See BÁRÁNY, Eduard. Pojmy dobrého práva. Bratislava: Eurokódex, 2007, p. 342. 
revolution and the Member States were not unified in some federal union by a single constitutional text. Member States are still present as building blocks of the EU. Despite the pressure of integration, they have not been swallowed by it. The Member States are the original holders of competences and remain independent units.

The fact is that current state of integration is correlated with certain degree of constitutional tensions which call for new definitions of the roles of the nation states in the EU. European integration entity ceased to be just a forum for negotiations between independent and sovereign nation states. To some extent it overlaps with the states and becomes their competitor. In this context, the classical concept of state sovereignty loses its original content and meaning. The participation in the integration project opens the question whether it takes away or weakens sovereignty of Member States. Stephen Weatherill opens the similar questions: 'Was [the process of integration] State-building? State-replacing?"3

The research objective of this paper is to analyse abovementioned questions in relation with the Czech Republic. The debate over the meaning of a state sovereignty vis-á-vis European integration devotes distinct attention especially in connection with the CEE countries. The experience with the so-called Brezhnev doctrine, which led to the real suppression of sovereignty of the Soviet satellites, gave rise to the constitutional accentuation of the state sovereignty in these countries. ${ }^{4}$ Newly regained freedom became an important constitutional value and therefore it was anticipated that the constitutional authorities in new Member States would be much more sensitive about loss or weakening of their sovereignty in connection with the European integration than their Western counterparts. ${ }^{5}$ The outcome should be a harmonization of Czech statehood (and the constitutional requirement that 'the Czech Republic is a sovereign, unitary and democratic, law-abiding State, based on respect for the rights and freedoms of man and citizen', chapter one, art. 1(1) of the Constitution) with its participation in the European integration project.

I put on four arguments to proof the hypothesis that Czech Republic continues to be a sovereign country even after accession to the European Union:

1. Sovereignty of Member State could be preserved if we skip into the new understanding of this theoretical construct while interpreting the constitutional requirements.

3 See WEATHERILL, Stephen. Cases and Materials on EU Law. 9th edition. Oxford: Oxford University Press, 2010, p. 647.

4 See AZIZ, Miriam. The Impact of European Rights on the National Legal Cultures. Oxford: Hart Publishing, 2004, p. 55 an.

5 For more, see SADURSKI, Wojciech. 'Solange, chapter 3': Constitutional Courts in Central Europe - Democracy - European Union. EUI Working Paper Law, č. 2006/40, s. 10. [online]. Available at <http://cadmus.eui.eu/dspace/bitstream/1814/6420/1/LAW -200640.pdf>. 
2. Sovereignty as the normative superiority is underlined by the constitutional claim of inviolability of core constitutional values.

3. Member States still remain in the position of Master of Treaties which gives them strong position in the future forming of European project.

4. Member States have an explicit right to withdraw from the Union so they are free to make decisions about their future 'European Destiny".

First two of the abovementioned claims are rather internal/national. They are based on the analysis and evaluation of the case load of Czech Constitutional Court (CCC). CCC has issued a wide range of decisions regarding the conceptual comprehension of national sovereignty, relationship between the Czech and supranational law, constitutional limits of EU law applicability and about role of of general and constitutional judiciary in the context of the Czech EU membership (see for example, Pl. ÚS 50/04, Pl. ÚS 66/04, Pl. ÚS 36/05, II. ÚS 1009/08, Pl. ÚS 19/08, Pl. ÚS 5/12). The Court has acknowledged that membership in a supranational organization brings changes and challenges to the system of national law, imposes new obligations on national institutions, but in the same time that it cannot lead to a disintegration of Czech statehood.

Later two arguments are rather supranational. The system of vertical relations between EU and Member States and vertical division of powers includes number of tools which increases the relevance of Member States. One may point for instance on the principle of mutual loyalty based on the art. 4 TEU or possibility of the restoration of competences from the EU back to the Member States (art. 48 para 2 TEU in relation to primary law, declaration no. 18 of the Final Act of the IGC which adopted the Treaty of Lisbon). Among these 'state-strengthening-measures" two are of significant relevance for my claims. Possibility to model the EU by the Treaty revisions and right to withdraw from it clearly shows that Member States are still crucial building blocks of the EU.

\section{Argument I: New definition of sovereignty as redemption of old concept}

The contradictions identified in the introduction (ongoing process of deepening of integration versus existence of Member States as building blocks) are interrelated with the need of hermeneutical reflexion and necessity to discover some new definition and understanding of state sovereignty. Indeed, sovereignty as is an old concept which is traditionally understood as being fixed and static. But on the other hand it is the term which is highly contested vis-á-vis bird of modern international law, European integration and globalization. ${ }^{6}$ The CCC

6 In the current theory of international law a new institutions like Responsibility-to-Protect (used to legitimize the humanitarian interventions) or so-called Annan doctrine (understanding States as servants of the needs of their inhabitants. See ANNAN, A. Kofi. Two Concepts of Sovereignty. The Economist, 18. 9. 1999) start to appear and give rise to the concept of ethical sovereignty, see MINKKINEN, Panu The Ethos of Sovereignty: A Critical Appraisal. Human Rights Review, 2007, vol. 8, no. 2, p 33-51. 
reflected this fact a need in its Lisbon rulings in 2008 and 2009. In this decisions CCC claimed for the flexible understanding of sovereignty and based the reconciliation of the sovereign statehood with the European integration by using the concept of shared/pooled sovereignty.

The CCC understands sovereignty as a responsibility for securing a high standard of the existence of society and as a prerequisite for economic reproduction and reproduction of the states' value base. Acceptance of pooled sovereignty was to some extent a judicial revolution. ${ }^{7}$ But one cannot evaluate it as surprising or unexpected. The institute of state sovereignty had undergone a transformation and gained new proportions. It is no longer solely an attribute of a nation state and an expression of its power over the controlled territory. The current concept of sovereignty is necessarily connected with the state's willingness and will to participate in venues of international cooperation and to share its competences with other subjects of international community. Sovereignty is a manifestation of the new order in a globalized world. ${ }^{8}$ Economies and decision-making processes become interdependent here. We are facing the phenomena of mixed responsibility and appearance of new decision making centres. All of that calls for new approaches to old institutions and concepts. ${ }^{9}$ European integration as a projection of shared common goals and more importantly shared competences ignited the new approach and gave rise to concepts of shared or pooled sovereignty. ${ }^{10}$ This obviously inspired CCC and became the core of its argumentation: 'The European Union has advanced by far the furthest in the concept of pooled sovereignty, and today is creating an entity sui generis, which is difficult to classify in classical political science categories. It is more a linguistic question whether to describe the integration process as a 'loss' of part of sovereignty, or competences, or, somewhat more fittingly, as, e.g., 'lending, ceding" of part of the competence of a sovereign. It may seem paradoxical that they key expression of state sovereignty is the ability to dispose of one's sovereignty (or part of it), or to temporarily or even permanently cede certain competences. ${ }^{.11}$

7 Constitutional Court adopted the theoretical concept of pooled sovereignty in its binding judicial decision and thus disproved arguments that the position of judges is different from the position of theoreticians and that such concepts cannot find real ground. (For more on this sceptical view, see KURTULUS, Ersun. State Sovereignty. Concept, Phenomenon and Ramifications. New York: Palgrave Macmillan 2005, p. 144-145.)

8 Point 102 Constitutional Court's ruling of 26 November 2008, Pl. ÚS 19/08 Treaty of Lisbon I.

9 Similarly, ZEMÁNEK, Jiří. Přezkum ústavnosti Lisabonské smlouvy: obsahové otázky. Jurisprudence, 2009, vol. 18, no. 1, p. 34.

10 Legal and political theories introduce them in connection with European integration. See WALLACE, William. The Sharing of Sovereignty: the European Paradox. Political Studies, 1999, vol. 47, no. 3, p. 503-521. WILLIAMS, Shirley. Sovereignty and Accountability in the European Community. The Political Quarterly, 1990, vol. 61, no. 3, p. 299-317.

11 Point 104 Constitutional Court's ruling of 26 November 2008, Pl. ÚS 19/08 Treaty of Lisbon I. 
Dividing (and pooling) of sovereignty is a reaction to the formation of a 'post national global society' ${ }^{12}$, which has become possible because sovereignty was redefined and lost its original meaning (as one highest, undividable power). Today, a sovereign should be mainly able to well organize the functioning of the society, to accept or tolerate the realities of integration and globalization. Sovereignty then expresses the state's capability to secure social needs and protect individuals in a global context. State is not sovereign because it holds in its hands the highest, unique and absolute power over a certain territory and its population, but because it preserves a minimal pool of instruments necessary to protect the interests and needs of its population. A state's sovereignty is not threatened by the transfer of some competences to the EU level but by the loss of the ability to serve the good of its society and its components.

The concept of sharing competences between Member States and the EU based on voluntary participation and displaying autonomous control mechanisms represents a foundation for deviation from the traditional closed understanding of state sovereignty. EU membership and the concept of pooled sovereignty carry many advantages for the Member States what counterbalances the obligation to tolerate the consequences of actions carried out by the EU institutions. Each sovereign state decides whether it will participate on the EU project or not. Voluntary losses (understood as the shift of the decision-making centre for a specific part of competences to the supranational level) then do not interfere with sovereignty. The CCC reminds us that Member States must accept a sum of obligations, and must respect established formal processes because they (voluntary) participate on the construction of the European supranational entity. It specifically states that: ' $[\ldots]$ in a modern democratic state governed by the rule of law, the sovereignty of the state is not an aim in and of itself, that is, in isolation, but is a means for fulfilling the fundamental values on which the construction of a democratic state governed by the rule of law stands. [...] the transfer of certain state competences, that arises from the free will of the sovereign, and will continue to be exercised with the sovereign's participation in a manner that is agreed upon in advance and is subject to review, is not a conceptual weakening of sovereignty, but, on the contrary, can lead to strengthening it within the joint actions of an integrated whole. [...] the European Union has advanced by far the furthest in the concept of shared - 'pooled" - sovereignty, and today already forms an entity sui generis, which is difficult to classify in classical political science categories. A key manifestation of a state's sovereignty is the ability to continue to manage its sovereignty (or part of it), or to cede certain powers temporarily or permanently.13 In this view states do not lose their sovereignty

12 As Jiří Přibáň defines the current state of affairs in his essay/article. See PǨIBÁŇ, Jiří. Vlast nebo domov? Česká otázka v postnacionální společnosti. Novinky.cz. [online]. Available at $<$ http://www.novinky.cz/kultura/salon/282596-jiri-priban-vlast-nebo-domov.html>.

13 Point 147 Constitutional Court finding of 3 November 2009, Pl. ÚS 29/09 Treaty of Lisbon II. 
by pooling it, they only shift the responsibility for political decisions to a supranational authority and to some extent trade the ability to adopt their own solutions for the advantage of higher effectiveness within the bounds of a common project. $^{14}$

The CCC chose the flexible understanding of sovereignty in the form of a theory of a shared or pooled identity, and so it established conditions for harmonizing two requirements of the Czech constitutional law (Art 1 para 1: 'The Czech Republic is a sovereign, unitary and democratic, law-abiding State, based on respect for the rights and freedoms of man and citizens' and Art 1 para 2: 'The Czech Republic shall observe its obligations under international law.'

Flexible perception of sovereignty in the ideal world of concepts allows the preservation of Czech sovereignty and confirms the hypothesis that by acceding to the EU, the Czech Republic did not lose the position of a sovereign state. Committing some of its original competences to the supranational institutions does not lead to a loss or depreciation of sovereignty. On the contrary, the collective management of issues of common interest strengthens it.

\section{Argument II: Czech Constitutional Court as the final arbiter in the com- petence conflicts}

The nature of EC/EU law has been essentially connected with the supranational nature of European integration. Meeting the autonomous objectives of integration requires an autonomous, effective and unified legal system. A new law-maker other than a nation state unavoidably emerged here. Ability to regulate the behaviour and conduct of society abandoned the exclusive monopoly of state power and thus opened way for a pluralistic set-out. The autonomous nature of the EU law logically resulted in a certain ability to autonomously determine its effects on its territory, and as such to influence legal practice of the Member States. So, the internal effects of the EU law are not left solely up to the good will of the Member States. We cannot apply the traditional concepts of dualism and monism, which regulate the forms in which international law applies on the national level and determine the mutual relations $f$ these two systems. On the contrary, the EU law defines its effects autonomously and gives rise to the Member State's obligation to apply supranational rules.

Court of Justice claims that independent character, binding force and efficiency of EU norms require full and unitary application of EU law from the moment of its adoption and throughout its legal 'existence" in all Member States. The Court of Justice does not distinguish between EU and national laws in their application by national courts and public authorities. On the contrary, it establishes that the EU legal provisions are indispensable parts of the Member States'

14 LAKE, A. David. Delegating divisible sovereignty. Sweeping a conceptual minefield. The Review of International Organizations, 2007, vol. 2, no. 3, p. 231-232. 
legal systems (26/62 Van Gen den Loos ${ }^{15} ; 106 / 77$ Simmenthal ${ }^{16}$ ). Direct (immediate) applicability includes a command for the national courts to accept supranational law as their own and apply it as originally adopted, i.e. without transposition into national law. ${ }^{17}$ National authorities must accept EU law as an integral part of their national legal system. But moreover they have to consider the content and objectives of the EU when interpreting national norms (principle of indirect effect ${ }^{18}$ ). Principles of direct and indirect effect build together the very wide arena for the penetration of the supranational regulation into the national practice. But once the normative ideas of the supranational legislator come into the effect in national practice the risk arises that they will get into the conflicts with concurring national norms, which forms another independent - national - system of law. To solve this clashes Court of Justice introduced another crucial principle of EU law - the principle of primacy. ${ }^{19}$ According to that principle when a conflict between EU law and national law arises, national authorities need to give preference to the European norm and not apply the national one. The main principles of application clearly show that EU law behaves vis-á-vis national law as a dominant legal system. If the EU law collides with the wording or meaning of national norms, it is this dominance which resolves the problem and causes that conflicting national rules will not be applied or that national law will be interpreted in line with the EU law requirements.

The penetration of EU supranational law into the national legal systems disrupts the 'sovereignty idol' - the traditional concept providing that a direct intervention of external norms into the legal system of a sovereign state is inadmissible. ${ }^{20}$ Thus, it is not surprising that in the landmark decision, which for the first time established the autonomy and internal effects of the EC law (26/62 Van Gend en Loos), the three opposing Member States (Germany, Belgium, and the Netherlands), argued that sovereignty had to be preserved. In this sub-chapter I will focus shortly on the reaction of the CCC to that supranational penetration and consequences for the 'sovereignty idol' mentioned above.

15 Court of Justice judgement of 5 Februray 1963, 26/62 NV Algemene Transporten Expeditie Orderneming van Gend en Loos vs. Nederlandse Administratie der Belastingen, ECLI:EU:C:1963:1.

16 Court of Justice judgement of 9 March 1978, 106/77 Amministrazione delle Finanze dello Stato vs. Simmenthal SpA, ECLI:EU:C:1978:49.

17 Sacha Prechal considers this 'obligation to apply' a crucial, central element of direct effect principle. See PRECHAL, Sacha. Direct Effect, Indirect Effect, Supremacy and the Evolving Constitution of the European Union. In BARNARD, Catherine (ed). The Fundamentals of EU Law Revisited. Assesing the Impact of the Constitutional Debate. Oxford: Oxford University Press, 2007, p. 38.

18 Court of Justice judgement of 10 April 1984, 14/83 Von Colson and Kamann vs. Land Nordrhein-Westfalen, ECLI:EU:C:1984:153.

19 See Court of Justice judgement of 3 June 1964, 6/64 Flaminio Costa vs. ENEL, ECLI:EU:C:1964:66.

20 See KLOKOČKA, Vladimír. Ústavní systémy evropských států. 2.ed. Praha: Linde, 2006, p. 242. 
First of all we must mention that once dealing with these supranational requirements, the CCC showed the pro-European attitude and acknowledged the autonomous character of EU law. In its seminal ruling Pl. ÚS 50/04 Sugar Quotas III it opened the Czech legal system to these principles by wide interpretation of the art 10a para 1 of Czech Constitution. The provision which (by its grammatical reading) just empowers the Czech Republic to transfer some of competencies to the international bodies ${ }^{21}$ was interpreted by the CCC as 'bidirectional" provision which also serves as a constitutional gate for the inclusion of EU principles to Czech legal system. In this view Czech constitution does not determine the mechanisms of internal application but only enables that already settled principles to get inside the national system and to blossom there. Once Czech legal system was opened to the EU law, the possibility of conflict between it and national law became plausible. We must state here that Czech Constitution lacks any direct determinant of the relationship between EU and national law. In order to resolve this constitutional vacuum, the CCC had to provide some interpretations. It used the carriage of Sugar Quotas case as a historical opportunity and drew the lines of the relations between EU and Czech law. It is worth to mention here that CCC continued in pro-European reasoning. As mentioned above, the CCC acknowledged the ability of the supranational system to determine the conditions of internal application of its norms autonomously. Secondly it refused its own capacity to evaluate the validity of supranational norms. ${ }^{22}$ And besides that CCC (being aware of the need to limit national law in favour of effective functioning of the EU) accepted also the principle of primacy as another characteristic feature of the EU law penetrating into the Czech legal system via the 'opening' clause in Art 10a of the Constitution.

Although CCC accepted the penetration of EU law very widely it was cautious about recognition of primacy as absolute and unconditional principle as claimed by the Court of Justice in case 11/70 Internationale Handelsgesellschaft. ${ }^{23}$ And finally it took a position which is in a line with the practice which Robert Schütze determines as a relative acceptation of the primacy principle at the national level. ${ }^{24}$ The arguments of CCC against the absolute meaning of pri-

21 Art 10a of the Czech Constitution states that: 'An international agreement may provide for a transfer of certain powers of bodies of the Czech Republic to an international organization or institution.'

22 Similar attitude stating it was impossible to evaluate the legality of EU law was adopted by the Polish Trybunał Konstytucyjny, which in its judgement of 31 April 2004, K 15/04 on participation of foreigners in European Parliamentary elections rejected the possibility to evaluate the legal institute of EU law based on the Polish Constitution because it could be applied only to relationships it regulates, i.e. not outside the Polish state. See TK Wyrok z 31 maja 2004, K 15/04 Udział cudzoziemców w wyborach do parlamentu europejskiego.

23 Court of Justice judgement of 17 December 1970, 11/70 Internationale Handelsgesellschaft mbH vs. Einfuhr und Vorratsstelle für Getreide und Futtermittel, ECLI:EU:C:1970:114.

24 See SCHÜTZE, Robert. European Constitutional Law. Cambridge: Cambridge University Press, 2012, p. 358-363. 
macy were based on the mechanism of transfer of competences. CCC did not consider this transfer as being unlimited. On the contrary, it based its reasoning on the concept of 'conditional conferral" and stated that: "[...] the delegation of a part of the powers of national organs may persist only so long as these powers are exercised in a manner that is compatible with the preservation of the foundations of state sovereignty of the Czech Republic, and in a manner which does not threaten the very essence of the substantive law-based state. [... ${ }^{\text {c25 }} \mathrm{CCC}$ wagged a warning finger and reminded that the transfer of competences is not definite and unconditional. Contrary to that, possibility to confer some original competences of the Czech Republic is limited by the necessity to protect some elementary values of the Czech constitutional system - its substantive heart. CCC hence allowed for a leeway to prevent the application (be it direct or indirect via national implementing measures or interpretation) of EU law that would be in contradiction to those inviolable principles. ${ }^{26}$ The 'so-long-as' approach of the CCC is clearly inspired by the case-law of its German Counterpart. German FCC also accepts the internal application of EU law only in conditional mode and leaves the open door for the scrutinizing whether EU regulation does not affects the German standards of protection of fundamental rights or German national identity. ${ }^{27}$

CCC repeatedly accentuated its 'so-long-as' attitude in its rulings concerning the Treaty of Lisbon. It observed that openness and positive attitude towards the autonomy of EU law did not deprive its own role as last arbiter and a guardian of the activities of EU institutions. ${ }^{28}$ But its argumentation in comparison to the Sugar Quotas case went a bit further. CCC stated that it is prepared to '[...] function as an ultima ratio and may review whether any act of Union bodies exceeded the powers that the Czech Republic transferred to the European Union under Art. 10a of the Constitution [...]. ${ }^{29}$ These words (repeated in its ruling for several times) clearly demonstrate the shift toward broader limitation of EU law dominance. According to that position CCC may not serve only as the guarantor of the untouchable substantive heart of the Constitution (the principles which are even out of the discretion of the Czech legislator and therefore could not be

25 Constitutional Court's ruling of 8 March 2006, Pl. ÚS 50/04 Sugar Quotas III.

26 Similarly, see MARŠÁLKOVÁ, Zuzana. Jak daleko sahá omezení pravomocí orgánů ČR po vstupu do EU ve světle nálezu Ústavního soudu ve věci cukerných kvót. Právní rozhledy, 2006, vol. 14 , no. 15 , p. 560.

27 FCC decision of 29 May 1974, BVerfGE 37, 271 (Solange I) Internationale Handelsgesellschaft mbH. v. Einfuhr - und Vorratstelle für Getreide und Futtermittel; FCC decision of 22 October 1986, BVerfGE 73, 339 (Solange II) Re Wünsche Handelsgesellschaft; FCC decision of 12 October 1993, BVerfGE 89, 155 Maastricht-Urteil; FCC Decision of 30 June 2009Rozhodnutí 2 BvE 2/08 Lissabon-Urteil.

28 For more see also ZEMÁNEK, Jiř́. A European Mandate of the Czech Constitutional Court. In KOCH, Henning et al. (eds). Europe. The New Legal Realism. Essays in Honour of Hjalte Rasmussen. Kodaň: DJØF Publishing, 2010, p. 840.

29 Point 120 Constitutional Court's ruling of 26 November 2008, Pl. ÚS 19/08 Treaty of Lisbon I. 
transferred on supranational level) but additionally it may serve also as supervisor of the conduct of EU institutions within the fields where they embrace the legislative capacity. Once more the inspiration came from the case-law of FCC which introduced the "ultra vires" test in its Maastricht decision. Thus the option of scrutinizing the EU norms broaden from let's say substantive constitutional review (resolving the potential clashes between EU norms and core constitutional values, crossing the line of the supra-constitutional ideals and some meta-legal spheres - sovereignty, identity, rule of law etc.) to more formal, technical review (evaluation the content and scope of EU norms vis-á-vis content and scope of conferred competences). In the first case, CCC could be able to refuse the EU rule simply because even national legislative action would be inadmissible here. In later case CCC could be able to refuse the EU rule because it covers the question which was not conferred to the EU (yet).

In the chapter evaluating the constitutional limits of the application of EU law in the Czech Republic, one cannot exclude the controversial decision in Slovak pensions case (titled also as Holubec case).$^{30}$ In this case CCC used its 'reservation to review' the EU norms, which was introduced in its previous case law and for the first time materially scrutinized the act of EU institution (this time the decision of the Court of Justice). And moreover it found the act of EU institution being ultra vires. But let's start with the short introduction on the circumstances of the case. In the past years CCC repeatedly stood up for the claims of Czech citizens, who were employed by an employer based in Slovak part of former federation, to receive a compensation payment up to the level of their hypothetical pension, which they would have been entitled to once they had worked in Czech part of common state. CCC introduced this compensation supplement scale as a reaction to the unjust consequences of the exceptional historical event - the dissolution of Czechoslovakia. According to the settled practice only Czech citizens residing in the Czech territory were entitled to this special financial supplement. However after accession of the Czech Republic to the EU, this practice entered into the Conflict with EU law requirements. It was claimed to be against the EU regulation on the coordination of social schemes, $\mathrm{EU}$ free movement rules and principle of non-discrimination on the basis of nationality. After series of national judicial tensions and conflicts between social security authorities, ordinary courts and CCC the question finally reached the Court of Justice as the preliminary question referred by the Supreme Administrative Court. ${ }^{31}$ Court of Justice in its judgement C-399/09 Landtová ${ }^{32}$ ruled that aforementioned special compensation was in breach with $\mathrm{EU}$ requirements. The main problem was it their discriminatory nature. Court of Justice did not reject the supplement as such but only practice which reserved it solely to the Czech

30 Constitutional Court ruling of 31 January 2012, PL. ÚS 5/12 Slovak Pensions XVII.

31 For the evaluation of the story see inter alia chapter of Jan JIRÁSEK in STEHLÍK, Václav, HAMULÁK, Ondrej et al. Unijní právo před českými soudy. Praha: Leges, 2014, p. 50-53.

32 ECJ judgment of 22 June 2011, C-399/09 Landtová, ECLI:EU:C:2011:415. 
nationals residing in the territory of the Czech Republic. Its opinion clearly did not oppose the endeavour of CCC to minimalize the social injustice connected with the split of Czechoslovakia (which I believe was the main reason for the introduction of compensation supplement). Even the Luxemburg decision was "mediatory" enough it did not mean the end of story. In another case the question of entitlement for the pension supplement once more reached the CCC. And CCC in its verdict from January 2012 refused the view of Court of Justice and proclaimed the ruling in Landtová case as ultra vires decision. In the view of CCC the question of Slovak pensions was totally outside the scope of EU law and therefore beyond the competence of the Luxemburg court. According to CCC the situations covered by the compensation scheme lack the foreign element as they were introduced as reaction on the exceptional historical event - the dissolution of Czechoslovakia where unitary social security system was used. CCC strongly blamed the Court of Justice for ignoring these historical circumstances and for ignorance of its own arguments and views. The very controversial findings of the CCC were based more on the emotional assumption than on the precise legal reasoning. There are plenty of commentaries which point on the gaps in the argumentation which I won't repeat at this place ${ }^{33}$ (Zbíral blames the 'very poor knowledge of EU law'; Komárek criticises CCC for its uncooperative nature, Bobek points on the side-incentives of the CCC: 'Holubec is an odd case about judicial weariness and judicial ego'). Even though Holubec decision gave rise to some doubts about destruction of the substile equilibrium ${ }^{34}$ settled between Luxemburg court and national authorities, its weak argumentation, emotional rather than rational nature and minimal reaction of the European institutions finally led to the calm assumptions, that the war between courts did not occurred yet. And besides that the Slovak pensions question seems to be the closed chapter because in the meantime the problem (with the discrimination) was resolved by the Czech legislator by adoption of new law. Let's leave aside the question whether Holubec case was rightly chosen vehicle for the CCC to get into the EU law textbooks. For the purpose of this paper this case serves as

33 See e.g. ZBÍRAL, Robert. Czech Constitutional Court, judgment of 31 January 2012, Pl. ÚS 5/12. A Legal revolution or negligible episode? Court of Justice decision proclaimed ultra vires. Common Market Law Review, 2012, vol. 49, no. 4, p. 1475-1492; KOMÁREK, Jan. Czech Constitutional Court Playing with Matches: the Czech Constitutional Court Declares a Judgment of the Court of Justice of the EU Ultra Vires; Judgment of 31 January 2012, Pl. ÚS 5/12, Slovak Pensions XVII. European Constitutional Law Review, 2012, vol. 8, no. 2, p. 323 - 337; BOBEK, Michal. Landtová, Holubec, and the Problem of an Uncooperative Court: Implications for the Preliminary Rulings Procedure European Constitutional Law Review, 2014, vol. 10, no. 1, p. 71.

34 Some scholars labelled this equilibrium as 'cold war' between courts, were nobody is seriously willing to use the "weapons of mass destruction" but time to time shows them as the potential threat. See WEILER, Joseph Halevi Horowitz, HALTERN, Ulrich. The Autonomy of the Community Legal Order --Through the Looking Glass. The Jean Monnet Working Paper, 1996, no. 10. [online]. Available at <http://centers.law.nyu.edu/jeanmonnet/archive/ papers/96/9610-The-2.html>. 
a message that the "so-long-as" attitude is not just an academic statement but it may occur in real cases. It proved the claim that CCC stands as a final arbiter and therefore it as a guarantor of our state sovereignty.

\section{Argument III: State as a "Creator and Master"}

It is clear enough that in the process of European integration Member States still figure as important players. Even the presence of defiance of the features which strengthen the EU and give it some state-like nature ${ }^{35}$ the EU as a state (federation) was not ultimately established. The 'final' step is just and only in the hands of its Member States. The self-regulating ability of the EU is not unlimited. On the contrary, the activities of the EU and the effects of its law are conditioned by the existence of a national base as found in the Czech constitutional order in Art 10a Constitution. It is the pouvoir constituant of all Member States and not the EU itself that holds the right to decide over the sum of competences which should be conferred to the EU. ${ }^{36}$ On account of this, the states are still responsible for the moderating the nature of the EU. ${ }^{37}$ In relation to this CCC pointed to the fact that even after the big Lisbon reform it should still hold true that 'the legislative competence - competence, i.e. the authorization to amend fundamental regulations, remains with the member states. This is closely tied to the doubts of the Senate and the president concerning the character of the EU as a federal state, or the classification of powers that, according to the Senate and the president, such a state is to point out; we can briefly draw from this that if the Union does not have the competence-competence, it cannot be considered either a kind of federal state or special entity, standing in every respect and always above the individual states. The Union can act only within the scope of powers expressly conferred on it by member states, which it cannot exceed, nor can it establish new powers for itself. Article 5 par. 2 of the Treaty on EU provides: "Under the principle of conferral, the Union shall act only within the limits of the competences conferred upon it by the Member States in the Treaties to attain the objectives set out therein. Competences not conferred upon the Union in the Treaties remain with the Member States. [...]. ${ }^{38}$

The European Union even though it is a supranational organisation it does not absorb its Member States. Those are still sovereign subjects and they serve as the foundation stones of the European Union - which is still their product. The principle of sincere cooperation (principle of loyalty) included in the Article

35 On gradual transformation of the EU to a state-like entity, see also PROCHÁZKA, Radoslav. Európska únia ako štátny zväzok. Justičná revue, 2005, vol. 57, no. 1, p. 96-103.

36 Similarly, see for instance KYSELA, Jan. Lisabonská smlouva v kontextu předběžného přezkumu Ústavním soudem. Právní zpravodaj, 2008, vol. 9, no. 6, p. 5.

37 In the same spirit, see ZEMÁNEK, Jiří. Kompetenční a hodnotový rámec Evropské unie v 'lisabonském’ nálezu Ústavního soudu. In GERLOCH, Aleš, WINTR, Jan (eds). Lisabonská smlouva a ústavní pořádek. Plzeň: Aleš Čeněk, 2009, p. 136.

38 Point 132 Constitutional Court ruling of 26 November 2008, Pl. ÚS 19/08 Treaty of Lisbon I. 
4(3), forms the groundwork of the Union's functioning. It is because under this principle both Union and Member States help each other in fulfilment of integrations tasks.

The crucial element in defining the position of the Member States is connected with their functions within the Treaty revision processes. The primary EU law is with not doubt a result of an agreement between Member States. The Member States have the main responsibility for its amendment and revisions. Considering this fact they are often designated as "Masters of the Treaties“. A procedure of revision of the primary legislation is governed by the Article 48 TEU. There are two revision procedures to amend or change the text of Treaties and in both of them Member States play the crucial role.

The ordinary revision procedure is a general form of a Treaty revision and it shall be used if the objective of modification is to change significantly the content of the primary law. The competences conferred upon the Union may be both extended and reduced by this procedure. This procedure may be initiated by the government of any Member State, the European Parliament or the Commission. The proposal is submitted to the Council which postpones the proposal to the European Council. The European Council decides about a proposal by a simple majority after the consultation with the European Parliament and the Commission. In case of the adoption of the positive decision, the President of the European Council convenes the Convention, a special body whose task is to consider the proposal and carry out the consensual text of amendment to the primary law (the Convention may not be convened in case of marginal amendments). After the Convention reaches a consensus and adopts particular recommendations, the President of the Council convenes a conference of representatives of the governments of the Member States where the text of the amending Treaty to the primary law is adopted. The amendments shall enter into force after being ratified by all the Member States.

The simplified revision procedures shall be used for less important issues. The Treaty governs two subcategories of the simplified revision procedure. Procedure under article 48 (6) includes revisions of all or part of the provisions of Part Three of the Treaty on the Functioning of the European Union relating to the internal policies and the action of the Union. Considering the wide range of questions potentially touched by this procedure a significant restriction was introduced. According to this restriction, the simplified procedure may not lead to the extension of competences conferred upon the European Union by the Member States. Amendments should thus concern organisational and institutional issues or lead to certain clarifications etc. The government of any Member State, the European Parliament or the Council may submit amendments under this procedure. The European Council decides about these amendments unanimously after the consultation with the European Parliament and the Commission (the European Central Bank in the case of institutional changes in the mon- 
etary area). The decision shall enter into force after approval by all Member States made under their internal constitutional rules. The second category of amendments under Article 48(7) TEU contains a so called general passerelle clause. In accordance with this clause the European Council (by unanimous decision) may change the provisions of the TFEU which provide for the Council to act by unanimity in a given area in manner that for the future qualified majority in that area shall be used (this can't be used in connection with decisions with military implications or those in the area of defence). The same may apply to all provisions of the TFEU that require a special legislative procedure for adoption of a secondary law acts. Here the European Council shall decide that in the future an ordinary legislative procedure shall be used instead. Any initiative within this procedure shall be submitted to the national parliaments. Any of them has the right to manifests its opposition within the six months period. In case of objections this procedure of the Treaty revision shall be stopped (this right to prevent the adoption of the revision of Treaties by national parliaments is designated as a "red card" mechanism). In case when no opposition has been made, the European Council could by the unanimous decision and with the consent of the European Parliament adopt proposed change of the primary law. It is important to mention here that simplified revision procedures fall under the scrutiny of Court of Justice. Although changes of primary law in general cannot be reviewed by the Luxembourg Court here the Court reserved itself a right to have control over procedural and formal aspects of revision. ${ }^{39}$

When we look on both variations of the Treaty revision processes it is clear that position of the Member States (their particular bodies) if ultimate notwithstanding the efforts to move a responsibility for at least simple amendments to the supranational level. Member States individually still possess the right of veto (in active or passive mutation) to any proposed change. ${ }^{40}$ As the CCC rightly stated: '[...] The system of amending primary law, as enshrined by the Treaty of Lisbon, is proof that all the named international treaties remain such treaties even as regards revision of them, and therefore the European Union, even after the Treaty of Lisbon enters into force, will be a unique organization of an international law character. In a federative state, it is primarily up to the federal bodies to adopt amendments of the constitution; the member states of a multi-member federation, if they even take part in such a constitutional amendment, need not all agree with a constitutional amendment, and yet the amendment will enter into force. In contrast, amendment of the Treaty on EU or of

39 See judgment of the Courtof Justice of 27 November 2012, C-370/12 Pringle, ECLI:EU:C:2012:756. For case-report see DE WITTE, Bruno; BEUKERS, Thomas. The Court of Justice approves the creation of the European Stability Mechanism outside the EU legal order: Pringle. Common Market Law Review, 2013, vol. 50, no. pp. 805-848.

40 Similarly see BŘİA, Petr. The Czech Republic: The Constitutional Court on the Lisbon Treaty Decision of 26 November 2008. European Constitutional Law Review, 2009, vol. 5, no. 1, p. 152. 
the Treaty on the Functioning of the EU will be possible only with the consent of all states in the Union at an intergovernmental conference, so the role of Union bodies would be only a matter of order, not decisive; thus, Union bodies will not decide on the proposed amendments, but only organize the revision of treaties, and the amendments will enter into force after ratification by all member states in accordance with their constitutional regulations (see Art. 48 par. 1 to 5 of the Treaty on EU). Thus, even after the Treaty of Lisbon enters into force, the EU will not acquire the power to create its own new competences, the member states will still be "masters of the treaties." ${ }^{41}$ Control over the Treaty amendments is important sign of preservation of the sovereign position of Member States. German FCC went in this question even further than CCC. In its Lisbon decision it introduced the constitutional obligation of the German bodies to perform the so-called Integrationsverantwortung - a permanent responsibility for the integration process. According to this constitutional obligation all proposal for the revision of the Treaties must be approved by the Act of German Parliament. This approval preserves the legitimacy chain between German demos and decisions on the European level. ${ }^{42}$

The position of Member States as Masters of the Treaties is reflected also in the setting of the EU enlargement process (Art 49 TEU). The interests of both the $\mathrm{EU}$ and its Member States are reflected in this process, which is attended by both the supranational and national institutions. The potential candidate country files a membership application with the Council, which informs the European Parliament and all national parliaments. The first decision is made at the EU level when the Council (unanimously) decides about the application upon consulting the Commission and with the assent of the European Parliament (decides by a majority of all MEPs). If the Council and the European Parliament give a positive decision, negotiation and the adoption of an accession treaty follow. The parties of this Treaty are the candidate country and the current EU Member States. Its adoption (signing the treaty) is followed by a ratification process in all Member States according to their national rules. The accession treaty enters into force after a successful ratification by all contracting parties (in current situation it would require $27+1$ ratifications). Every Member State can veto the new member's accession on two different occasions (in the Council vote or in a national ratification). In the accession process, i.e. quantitative and territorial change of the European Union, states can act as autonomous players, as sovereigns protecting their interests (geopolitical, economic, and historical).

Finally, the fundamental role of states is highlighted by the emphasis on the reciprocity of integration (so called reciprocal flexibility). This reciprocity is displayed by the explicit reference to the possibility of a negative treaty revision in

41 Point 146 Constitutional Court's ruling of 26 November 2008, Pl. ÚS 19/08 Treaty of Lisbon I.

42 See further GRIMM, Dieter. Defending Sovereign Statehood Against Transforming the Union Into a State. European Constitutional Law Review. vol. 5, no. 3, p. 360-361.

\section{(c) Palacký University Olomouc, Czech Republic, 2014. ISSN 1213-8770 (print), ISSN: 2464-6601 (online).}


the form of restricted EU competences (Art 48 para 2 second sentence TEU), and also in the form of introducing the possibility of Member States initiating negative legislative activity when based on the declaration no. 18 Final Act of the Intergovernmental Conference which adopted the Treaty of Lisbon, every Member State, individually or in alliance with other states, has the right to nominate the Council to ask the Commission to present a proposal for the abolition of legislation. Thus, in the area of shared competences the Member States will have received a possibility to regain a shared competence which the EU does not use or to defend its competences in case the adoption of such legislative act that violated the principles of transferred competence. ${ }^{43}$

The Lisbon reform of primary law was based on the concept of balancing when the increase in 'federalizing element' was accompanied by reform steps increasing legitimacy of decision-making in the EU and strengthening Member States' supervision possibilities. ${ }^{44}$ Primary example of this 'counter-arrangement' is a new system for controlling, that the subsidiarity principle is observed when EU legislation is drafted by engaging the national parliaments according to Protocol (no. 2) on the application of the principles of subsidiarity and proportionality (Art 4$){ }^{45}$ Every proposed legislative act must be submitted to the national parliaments of all Member States. These see to the observation of the subsidiarity principle. National parliaments have the possibility to express their view (in the form of the so called reasoned opinion) on the proposed legislative act. The cooling-off period was set to eight weeks. In case that one third of parliaments ${ }^{46}$ raises an objection to the proposal, the institution which presented it is obliged to take these objections and observations into consideration and decide if it will keep, change or withdraw the proposal (the so called 'yellow card' right). If at least a simple majority of national parliaments objects the Commission's proposal and the Commission upon the examination of their observation decides to keep the proposal, it must duly justify it. The positions of the national parliaments and Commission, is then together with the proposal submitted to the European Parliament and Council. The EU norm maker has to take into consideration both alternative views and come to terms with submitted proposals when adopting the act (the so called 'orange card' right).

43 On state manifestations of 'reciprocal flexibility' see BELLING, Vojtěch, MALÍŘ, Jan, PÍTROVÁ Lenka. Kontrola dělby pravomocí $\mathrm{v}$ EU se zřetelem ke kompetenčním excesům. Praha: Ústav státu a práva AV ČR, 2010, p. 29-30.

44 On the constitutional dimension of the Lisbon reform and the balancing of deepening politcal integration, see also ZEMÁNEK, Jiří. Ústavní rozměr členství v Evropské Unii a otázka souladu Lisabonské smlouvy. In MALÍř Jan et al. Česká republika v Evropské unii (2004-2009). Institucionální a právní otázky členství. Praha: Ústav státu a práva AV ČR, 2009, p. 34-54.

45 For more see for example ANDOURA, Sami et al. The Treaty of Lisbon: Implementing the Institutional Innovations. Brussels: CEPS, EGMONT, EPC, 2007, p. 81-96.

46 Each national parliament disposes of two votes: in case of two chambers, each house possesses one vote. 


\section{Argument IV: Membership in the Union is not our duty}

The Member States are the original holders of competences and act as a Master of the Treaties but moreover they remain as independent units capable to make the own decision about their future. Their right to withdraw from the Union, which was introduced by the Treaty of Lisbon (see Art. 50 TEU) underlines this fact. Member States must be understood as the "holders of their own destiny", the masters in the Schmittian extreme situation. Carl Schmitt commences his Political Theology by famous entence that 'sovereign is who decides on the exception. ${ }^{37}$ Here the exemption means not to be the one of the Member States. Until the Lisbon Treaty came into effect, the EU law did not regulate the possibility of a Member State to voluntary leave the EU. This possibility was admissible, however, due to the contractual foundation of the Community/ Union, which would allow a state to end its commitments arising from the Treaties and therefore end its membership in the Community as regulated by the rules of international law (1969 Vienna Convention on the law of treaties).

Voluntary membership in international organizations was always seen as a basis of state sovereignty. It was the case even with the historically first global integration organization - League of Nations. Voluntary membership was also in its case the (positive) answer to the question whether states which joined an international organization and so accepted certain limitations on their sovereignty can still be seen as sovereign subjects. ${ }^{48}$

As mentioned above, the option to leave the $\mathrm{EU}$ is currently regulated in Art 50 TEU. A state's withdrawal from the EU has to be first of all a consensual process. A Member State wishing to withdraw notifies its intention to the European Council, which provides guidelines for the conclusion of an agreement setting out the arrangements for its withdrawal. These negotiations are on behalf of the EU conducted by a negotiator (Art 218 para 3 TEU) and when the negotiations are completed, the agreement is concluded on behalf of the European Union by the Council, after obtaining the consent of the European Parliament. The EU institutions can thus affect the process of a state's withdrawa ${ }^{49}$, but not the withdrawal itself. The withdrawal agreement is not an absolute condition of membership termination. If the agreement is not agreed on or is not accepted, member-

47 'Sovereign is he who decides on the exception.' See SCHMITT, Carl. Political Theology: Four Chapters on the Concept of Sovereignty. Překlad George Schwab. Cambridge, Massachusetts: The MIT Press, 1985, p. 5.

48 For more see LE FUR, Louis. Nástin mezinárodního práva veřejného. Praha: Orbis, 1935, ps. 73,74 .

49 Mattias Kumm labelled the participation of institutions on the withdrawal process (then according to the draft Constitutional Treaty) as a display of Europeanization of residual national sovereignty. For more see KUMM, Mattias. To be a European Citizen: Constitutional Patriotism and the Treaty Establishing a Constitution for Europe. In ERIKSEN, Erik Oddvar et al. (eds). The European Constitution: the Rubicon Crossed? Oslo: Arena, 2005, p. 26 an. 
ship comes to an end two years after the Member State declared its intention to the European Council. Accession and withdrawal are autonomous rights of the states and their membership is their privilege, which cannot be taken away by a decision of an institution or a decision of other Member States - EU law does not make it possible to expel a state from the Union by the decision of others.

\section{Conslusions}

Even after accession to the EU the Czech Republic did not lose the status of a sovereign state, it did not lose its statehood. Authorizing supranational institutions to exercise power over some of its original competences does not imply loss or depreciation of national sovereignty. Even when we accept that EU is a holder of certain amount of sovereignty there are still enough "security checks" to claim that our country keeps its own statehood. ${ }^{50}$ In order to be able to articulate such a claim, we need to accept a shift in our traditional understanding of national sovereignty from a classical, static definition to a more open and dynamic concept. EU membership does not imply a loss of national sovereignty, but it requires modifications in its traditional understanding. Favouring an open concept of shared sovereignty guarantees the preservation of the state sovereignty as a constitutional ideal. Above and beyond, we can simply claim that the Czech Republic is in charge. As a state based on the rule of law, it cannot in its very nature accept the supremacy of EU law over all national law, and so it maintains some structural sovereignty. Despite the undeniable impact of the EU law on Czech law, the recognition of direct effect and the acceptance of its supremacy, Czech law shows certain basic structural elements, which are immune to the pressures of the supranational legal system. Inter alia the core values of the Czech Constitution and the right of the CCC to review whether actions of the European institutions did not went beyond the scope of conferred competences are the best examples. Moreover the general position of the Member States as the Masters of the Treaties and constitutional right of each Member States to withdraw the EU stands as another argument in favour of preservation of national sovereignty of the Czech Republic.

\section{Acknowledgements}

This paper was written within the project reg. no.: OPVK CZ.1.07/2.3.00/30.0041 (Podpora vytváření excelentních výzkumných týmů a intersektorální mobility na Univerzitě Palackého v Olomouci II - POST-UP II) which is financially supported by the European Social Fund an state budget of the Czech Republic.

50 On the reconciliation between sovereign statehood of the Member States and the partial sovereignty of the EU see also LOCK, Tobias. Why the European Union is not a State. European Constitutional Law Review, vol. 5, no. 3, p. 407-420. 